\title{
Working Capital Management (WCM) and Firm Performance in Emerging Markets: A Case of Bangladesh
}

\author{
Rafiqul Bhuyan ${ }^{1}$, Mohammad Sogir Hossain Khandoker ${ }^{2}$, Noshin Tasneem² \& Mahjuja Taznin ${ }^{1}$ \\ ${ }^{1}$ Department of Accounting and Finance, Alabama A\&M University, USA \\ ${ }^{2}$ Department of Finance, Jagannath University, Bangladesh \\ Correspondence: Rafiqul Bhuyan, Department of Accounting and Finance, Alabama A\&M University, USA.
}

Received: March 7, 2020

Accepted: February 24, 2021

Online Published: February 25, 2021

doi:10.5430/afr.v10n1p36

URL: https://doi.org/10.5430/afr.v10n1p36

\begin{abstract}
We examine the impact of efficient working capital management on market value and profitability. Using secondary data on selected firms from Dhaka Stock Exchange we explore the effects of various working capital components (i.e. cash conversion cycle (CCC), current ratio (CR), current asset to total asset ratio (CATAR), current liabilities to total asset ratio (CLTAR), debt to asset ratio (DTAR), size and growth) to the firm's performance by looking firm's value i.e. Tobin's Q (TQ) and profitability i.e. return on asset (ROA) and return on invested capital (ROIC). Our results show that, for both food and overall manufacturing sectors, there is a significant association between working capital variables and firm's value \& return on assets, but an insignificant association with return on invested capital.
\end{abstract}

Keywords: working capital management, Tobin's Q, Return on Asset, Return on Invested Capital, Cash conversion cycle

\section{Introduction}

Working capital management (WCM) is as equally important as long-term capital management in adding values to share holders' wealth and in any firm's sustained performance. It is no difference for firms in developing economies where, inefficiency in working capital management can have significant negative impact in firm's profitability, liquidity management, and overall performance. Efficiency in working capital management is vital, especially for manufacturing sector as it accounts for over half of its total assets and thereby directly affects the profitability and liquidity of the company (Raheman \& Nasir, 2007). Trade credit and inventories influence firm value (see, for instance, Bao \& Bao, 2004; Emery, 1984). Maness and Zietlow (2004) develop two models of value creation that incorporate effective short-term financial management activities. Similarly, Schiff and Lieber (1974), Sartoris and Hill (1983), and Kim and Chung (1990) model the effects of working capital management practices on firm value. Sartoris and Hill (1983) and Kim and Chung (1990) provide models that focus on how the joint management of a firm's credit policies and inventories influences firm value. Although the notion that efficiency of WCM affects firm value seems to enjoy wide acceptance, the empirical evidence on the value effect of working capital investment is scarce (Baños-Caballeroet al., 2014). Most of the previous empirical research has focused on the working capital determinants (e.g., Garcia-Teruel \& Solano, 2010; Anagnostopoulou, 2012), policy practices (e.g., Afza \& Nazir, 2007; Pandey, Gupta \&Perera, 1997; Perera, \& Wickremasinghe, 2010; Bei \& Wijewardena, 2012) and relationship between WCM and accounting performance of companies (e.g., Deloof 2003; Padachi 2006). Majority of the empirical studies confirm a negative relationship between WCM measures and accounting profitability measures (e.g., Deloof, 2003; Lazaridis and Tryfonidis, 2006; Garcia-Teruel and Martinez Solano, 2007; Jayarathne, 2014).). Sometimes, insufficient working capital management may also lead to bankruptcy, even though their profitability constantly grows positive (Samiloglu \& Demirgunes, 2008). Every firm tries to maintain an optimum level of working capital management that maximizes the value of the firm (Deloof, 2003; Howorth \& Westhead, 2003; Afza \& Nazir, 2007). There is extant literature on working capital management focusing on firm's performance and growth (Lamberson, 1995; Shin and Soenen, 1998; Narware, 2004, Lazaridies and Tryfonidis, 2006; Padachi, 2006; Afza and Nazir, 2007; Chowdhury and Amin, 2007; Ganesan,2007; Raheman and Nasr,2007; Uyar, 2009;Mathuva, 2010; Mansoor and Muhammad, 2010;Valipour, Javad and Farsi (2012); Naimulbari, 2012 ). Bangladesh is considered as one of the promising and growing economies among the emerging countries in Asia. In this country, there are several manufacturing companies like Cement, British American Tobacco Bangladesh, Textile, Pharmaceutical, and GlaxoSmithkline Bangladesh. It would be interesting research question to explore how working 
capital management in such companies is impacting on its profitability an overall performance. Taking a sample of manufacturing companies listed in DSE (Dhaka Stock Exchange) we explore this question. Earlier studies focuses on the relationship between working capital management with the firm's profitability in the case of Bangladesh (Mansoor and Muhammad, 2010; Valipour, Javad and Farsi (2012); Naimulbari, 2012). We add to the current literature by studying the impact of working capital management on firm's market value and profitability of Bangladeshi companies.

\subsection{Literature Review}

The importance of working capital management is not new to the finance literature and the review of prior literature reveals that there exists a significant relationship between firm performance and working capital management. Efficient working capital management involves managing short-term assets and short-term liabilities in a way that provides balance to cope with short-term debts and avoiding unnecessary holdings in these assets. Vajasaradhi and Rao (1978) find that increases in the investment of current assets, resulted in higher carrying cost which is negatively affected the profitability of the sector by studying Indian public enterprise. In an empirical study on the interrelationship between working capital management and profitability of 31 companies in Tamil Nadu, Vijaykumar and Venkatachalam (1995) show negative influence of liquidity and positive influence of inventory turnover on profitability. Mallik and Sur (1998) conduct research in the Indian tea industry to assess the influence of inventory turnover and debtor turnover profitability and observe both negative and positive association. Shin and Soenen (1998) examine the relationship between a firm's profitability and net trade cycle and find that a strong relationship exists between the two variables. Sivarama (1999) derives a close association between profitability and working capital efficiency in the study of working capital management in the Indian paper industry. By using the cash conversion cycle as a liquidity indicator in Greek food industry, Lyroudi \& Lazaridis (2000) find significant positive relationship between cash conversion cycle and the traditional liquidity measures of current and quick ratios. They find a negative relationship between the current and quick ratios and debt to equity ratio and a positive relationship with the time's interest earned ratio. Bardia (2004) focuses on steel manufacturing sectors and concludes a favorable influence of the liquidity of the company on its profitability. Deloof (2003) performs similar studies on Belgian non-financial sectors using DSO, inventories, and accounts payable cash conversion cycle as a measurement tool for trade creditor, inventory policies and WCM respectively and reveals that corporate profitability would increase if the number of day's accounts receivables and inventories are reduced. Narware (2004) also finds similar evidence on fertilizing sector that an increase in a company's profitability was lower than a decrease in working capital ratio.

The cash conversion cycle has been broadly used as a key component representing working capital. One of the earlier studies done by Jose, et al (1996) for the twenty-year period from 1974 through 1993 of 2718 firms offers strong evidence that aggressive working capital policies indicate by shorter cash conversion cycle enhance profitability. Looking at manufacturing firms in Greece, Lazaridis and Tryfonidis (2006) also that show there is a statistical significance between profitability, measured through gross operating profit and the cash conversion cycle.

Padachi (2006) finds that high investment in inventories and in receivables are associated with lower profitability. Christopher and Kamalavalli, (2009), focusing on corporate hospitals in India show that working capital component namely current ratio, current assets to operating income and leverage negatively influence profitability. However, the study was done by Raheman \& Nazir (2007) on Pakistani manufacturing firms demonstrate a strong negative relationship exists between variables of the working capital management (represents by liquidity and debt) with the profitability of the firm. Whilst, Afza and Nazir (2007) through cross-sectional regression models on working capital policies, profitability and risk of the firms, find a negative relationship between profitability measures of firms and degree of aggressiveness on working capital investment and financing policies. Ganesan (2007) analyzes the working capital management efficiency of firms from the telecommunication equipment industry and finds evidence that even though "day's working capital" is a negative correlation to the profitability, it is not significantly impacting the profitability of the firm. While Chowdhury and Amin (2007) find a positive correlation between working capital management with the financial performance of the Pharmaceutical industries in Bangladesh. Kieschnick et al (2008) study the importance of working capital management on US firms and show that an extra dollar invested in net working capital on average lowers firm value. Uyar (2009) studies similar issues on manufacturing firms in Turkey and indicates that the firms with shorter CCC are more likely to be more profitable than the firms with longer CCC. Nazir (2009) analyzes on the impact of aggressiveness of working capital investment and financing policies on non-financial firms in Pakistan. They evaluate firm returns i.e. return on assets and Tobin's Q to represent market performance and indicate that firms adopting an aggressive approach towards working capital financing policy create more value to the firm while the inverse relationship between the aggressiveness of working capital investment 
policies on firm performance. Similar results are also found in Afza and Nazir (2007). Deelof (2003) analyzes a sample of Belgian firms, and Wang (2002) analyzes a sample of Japanese and Taiwanese firms, emphasizing that the way the working capital is managed has a significant impact on the profitability of firms and increase in profitability by reducing number of day's accounts receivable and reducing inventories. Soenen (1993), Shin and Soenen (1998), Deloof (2003), and Garcia-Teruel and MartinezSolano (2007) provide evidence that the profitability of a firm, measured by either return on assets or return on equity, is improved as the firm improves its management of its working capital (i.e. the profitability of a firm is inversely related to its cash conversion cycle). Eljelly (2004) finds that working capital management is one of the most important areas while making the liquidity and profitability comparison among firms, involving the decision of the amount and composition of current assets and the financing of these assets. The way of managing working capital can have a significant impact on both the liquidity and the profitability of the company (Shin \& Soenen, 1998). There are a very few empirical research conducted on working capital components and firm profitability in Bangladesh. Ahmed et al (2017) analyze the impact of working capital management on profitability of textile companies of Bangladesh conclude that there is a statistically significant relationship between working capital management and profitability. Hoque, et al (2015) study on working capital management and profitability on Cement Companies in Bangladesh and find that there is significant positive correlation between profitability and working capital components as well as the impact of day sales outstanding (DSO) on profitability ratios is negatively significant. Asaduzzam and Chowdhury investigate the effect of working capital management on firm profitability on the textile companies of Bangladesh and reveal that inventory of number of days, number of day's accounts receivables and cash conversion period are positively correlated with firm's profitability but the numbers of days accounts payable are negatively correlated. We strive to add to the lieterature by focusing on the impact of working capital management on firm's market value and profitability looking at food and overall manufacturing sectors.

\section{Data and Methodology}

We collect secondary data from Dhaka Stock Exchange (DSE) on 24 listed companies for the period ranging from 2010 to 2016. Out of these 24 companies 16 are food sector \& 8 companies are overall manufacturing sector). The sample data of 2017 is eliminated because of the calculation of growth and the recent data of fiscal year 2018-19 is not fully available. Ten variables including dependent and independent are used for the thesis purpose. Three measures are used as dependent variable namely, Tobin's Q (TQ) as a proxy for market value, while return on asset (ROA) and return on invested capital (ROIC) as the proxy for profitability. Profitability is used as a measure for corporate performance because it evaluates the efficiency with which plant, equipment, and current assets are transformed into profit (Kamal and MohdZulkifli, 2004). The independent variables are cash conversion cycle (CCC), current ratio (CR), a current asset to total asset ratio (CATAR), current liabilities to total asset ratio (CLTAR), debt to asset ratio (DTAR), size and growth. By using Gretl software, the correlation matrix between the variables and the Ordinary least square model has been applied. List of variables, their definition, and notation are presented in Table 1.

Table 1. Variables Used in the Analysis

\begin{tabular}{lcc}
\hline Variable Name & Notation & Operationalization \\
\hline $\begin{array}{l}\text { Dependents Variable } \\
\text { 1. Tobin's Q }\end{array}$ & TQ & $\frac{\text { Market Capitalaization }}{\text { Book Value of Total Asset }}$ \\
2.Return on Asset & ROA & $\frac{\text { Earning efore Interest Tax }}{\text { Total Asset }}$ \\
3. Return on Invested Capital & ROIC & Tet Income \\
Independents Variable & & \\
\hline
\end{tabular}


1. Cash Conversion Cycle

$\mathrm{CCC}$

CACLR

CATAR

CLTAR

DTAR
2. Current Asset to Current Liability Ratio

3. Current Asset to Total Asset Ratio

4. Current Liabilities to Total Asset Ratio

5. Debt to Total Asset Ratio

Days sales in inventory $(D S I)+$ Days sales outstanding (DSO)- Days payables outstanding (DPO)

$$
\begin{aligned}
& * D S I=\frac{\text { Inventories }}{\text { Cost of Goods Sold }} \times 365 \\
& * D S O=\frac{\text { Receivables }}{\text { Sales }} \times 365 \\
& * D P O=\frac{\text { Payables }}{\text { Cost of Goods Sold }} \times 365
\end{aligned}
$$

\section{Current Asset} $\overline{\text { Current Liabilities }}$

Current Asset

Current Liabilities

Total Asset

Total Debt

Total Asset

Ln $n_{\text {Total Asset }}$

$\frac{\text { Sales }_{1}-\text { Sales }_{0}}{\text { Sales }_{0}}$

6. Size

7. Growth

We develop three null hypotheses $\left(\mathrm{H}_{0}\right)$ and three alternative hypotheses $\left(\mathrm{H}_{1}\right)$ have been developed to find the significant relations between working capital with firm's market value and profitability.

$\mathrm{H}_{01}$ : There is no association between Tobin's $\mathrm{Q}$ and Working Capital Components

$\mathrm{H}_{11}$ : There is an association between Tobin's Q and Working Capital Components

$\mathrm{H}_{02}$ : There is no association between ROA and Working Capital Components

$\mathrm{H}_{12}$ : There is an association between ROA and Working Capital Components

$\mathrm{H}_{03}$ : There is no association between ROIC and Working Capital Components

$\mathrm{H}_{13}$ : There is an association between ROIC and Working Capital Components

In order to conduct our research we apply various tests such as (i) Test for stationary; (ii) Test for Heteroskedasticity; (iii) Test for Normality in residual using Gretl. Finally, to analyze data we apply the following regression model:

$$
\begin{aligned}
& \text { TQ } \\
& \text { it }=\beta_{0}+\beta_{1} \mathrm{CCC}+\beta_{2} \mathrm{CACLR}+\beta_{3} \mathrm{CATAR}+\beta_{4} \mathrm{CLTAR}+\beta_{5} \mathrm{DTAR}+\beta_{6} \mathrm{Size}+\beta_{7} \text { Growth }+\varepsilon \\
& \mathrm{ROA}_{\mathrm{it}}=\beta_{0}+\beta_{1} \mathrm{CCC}+\beta_{2} \mathrm{CACLR}+\beta_{3} \mathrm{CATAR}+\beta_{4} \mathrm{CLTAR}+\beta_{5} \mathrm{DTAR}+\beta_{6} \mathrm{Size}+\beta_{7} \text { Growth }+\varepsilon \\
& \mathrm{ROIC} \\
& \mathrm{it}=\beta_{0}+\beta_{1} \mathrm{CCC}+\beta_{2} \mathrm{CACLR}+\beta_{3} \mathrm{CATAR}+\beta_{4} \mathrm{CLTAR}+\beta_{5} \mathrm{DTAR}+\beta_{6} \mathrm{Size}+\beta_{7} \text { Growth }+\varepsilon
\end{aligned}
$$

Where, $\mathrm{TQ}_{\mathrm{it}}=$ market value of firm $\mathrm{i}$ for period $\mathrm{t} ; \mathrm{ROA}_{\mathrm{it}}=$ Return on asset of firm $\mathrm{i}$ for period $\mathrm{t}$; ROIC $\mathrm{C}_{\mathrm{it}}=\mathrm{Return}$ on invested capital of firm $\mathrm{i}$ for period $\mathrm{t} ; \mathrm{CCC}_{\mathrm{it}}=\mathrm{Cash}$ conversion cycle of firm $\mathrm{i}$ for period $\mathrm{t}$; $\mathrm{CACLR}_{\mathrm{it}}=$ current asset to current liabilities ratio of firm $\mathrm{i}$ for period $\mathrm{t}$; $\mathrm{CATAR}_{\mathrm{it}}=$ current assets to total assets ratio of firm $\mathrm{i}$ for period $\mathrm{t}$; $\mathrm{CLTAR}_{\mathrm{it}}=$ current liabilities to total asset ratio of firm $\mathrm{i}$ for period $\mathrm{t}$; DTAR $\mathrm{DT}_{\mathrm{it}}=$ total debt to total assets ratio of firm $\mathrm{i}$

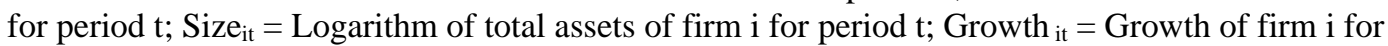
period $\mathrm{t} ; \varepsilon=$ error term of the model.

\section{Findings}

Table 2 provides the descriptive statistics for the sample. The mean value of TQ for the food sector is quite higher compared to the overall manufacturing sector (38.4 vs. 0.291) over the test period. This suggests that the market values of the food sector are higher compared to the overall market. The highest TQ in the Food sector is 191 while its lowest TQ is 1.84 (where it is 106 and -70.2 for other manufacturing companies). The mean, maximum and 
minimum values of ROA, ROIC, CLTAR, DTAR, Size and Growth are similar both for food as well as the manufacturing sector. The highest cash level for food and overall manufacturing company is 161000 while the lowest is 1340 and the optimum level is 15600 . The current ratio for food should be 2.05 and for manufacturing is to be 0.0146 . The minimum current ratio for food is 0.272 while the maximum is 6.02 in comparison with overall market index -3.05 and 4.04. The mean of current asset to total asset ratio for food is 0.602 while in manufacturing company the mean is 0.00219 .

Table 2. Descriptive Statistics

\begin{tabular}{lllllllll}
\hline \multicolumn{3}{l}{ Food Sector } & \multicolumn{5}{c}{ Overall Manufacturing Company } \\
Variable & Mean & S.D. & Min & Max & Mean & S.D. & Min & Max \\
\hline TQ & 38.4 & 42.4 & 1.84 & 191 & 0.291 & 26.1 & -70.2 & 106 \\
ROA & 0.000288 & 0.119 & -0.368 & 0.541 & 0.000288 & 0.119 & -0.368 & 0.541 \\
ROIC & 0.00974 & 0.131 & -0.447 & 0.473 & 0.00974 & 0.131 & -0.447 & 0.473 \\
CCC & 15600 & 28600 & 1340 & 161000 & 15600 & 28600 & 1340 & 161000 \\
CACLR & 2.05 & 1.02 & 0.739 & 6.02 & 0.0146 & 0.993 & -3.05 & 4.04 \\
CATAR & 0.602 & 0.234 & 0.272 & 1.00 & 0.00219 & 0.135 & -0.415 & 0.613 \\
CLTAR & 0.328 & 0.130 & 0.0958 & 0.653 & 0.328 & 0.130 & 0.0958 & 0.653 \\
DTAR & 0.467 & 0.129 & 0.238 & 0.775 & 0.467 & 0.129 & 0.238 & 0.775 \\
SIZE & 0.00234 & 1.21 & -5.69 & 5.02 & 0.00234 & 1.21 & -5.69 & 5.02 \\
GROWTH & 0.139 & 0.191 & -0.427 & 0.922 & 0.139 & 0.191 & -0.427 & 0.922 \\
\hline A & & & & &
\end{tabular}

Augmented Dickey-Fuller (ADF) Test is applied to test for the unit root of all dependent and independent variables. Under the ADF method, the null hypothesis is that there is no unit root in the data series. The significance level is considered at 5\%. All variables having unit root in both food sector and overall manufacturing sector are transformed by taking first differences on their levels to make the data stationary. Table 3 shows the results of the Unit Root Tests with and without constant $\&$ trend. After that, the modified data is used in the Ordinary least Square Model.

Table 3. Unit Root Test (With Constant \& Trend)

\begin{tabular}{|c|c|c|c|c|}
\hline \multirow[b]{2}{*}{ Variables } & \multicolumn{2}{|l|}{ Food Sector } & \multicolumn{2}{|c|}{ Overall Manufacturing Sector } \\
\hline & Level & $1^{\text {st }}$ Differentiate & Level & $\mathbf{1}^{\text {st }}$ Differentiate \\
\hline TQ & 0.04727 & - & 0.1509 & $1.222 \mathrm{e}-006$ \\
\hline ROA & 0.1074 & $3.604 \mathrm{e}-014$ & 0.1021 & $2.172 \mathrm{e}-009$ \\
\hline ROIC & 0.07793 & $1.487 \mathrm{e}-018$ & 0.1568 & $4.208 \mathrm{e}-008$ \\
\hline $\mathrm{CCC}$ & 0.002553 & - & 0.002553 & - \\
\hline CACLR & $1.482 \mathrm{e}-005$ & - & $1.482 \mathrm{e}-005$ & - \\
\hline CATAR & $1.657 \mathrm{e}-012$ & - & 0.2361 & $2.622 \mathrm{e}-008$ \\
\hline CLTAR & 0.0002467 & - & 0.00269 & - \\
\hline DTAR & 0.02745 & - & 0.004964 & - \\
\hline Size & 0.1065 & $3.587 \mathrm{e}-009$ & 0.3205 & $1.151 \mathrm{e}-005$ \\
\hline Growth & $4.633 e-015$ & - & $1.787 \mathrm{e}-010$ & - \\
\hline
\end{tabular}

With the Unit Root Test (With Constant \& Trend), the P-value of all the dependent and independent variables for all sectors is less than 0.05 rejecting the null hypothesis.

\subsection{Regression Results for Food Sector}

To test the effects of working capital management on firm value and profitability, a regression analysis is given using 112 firm-years observation and the results are presented in Table 4. 
Table 4. Regression Model for Food Sector

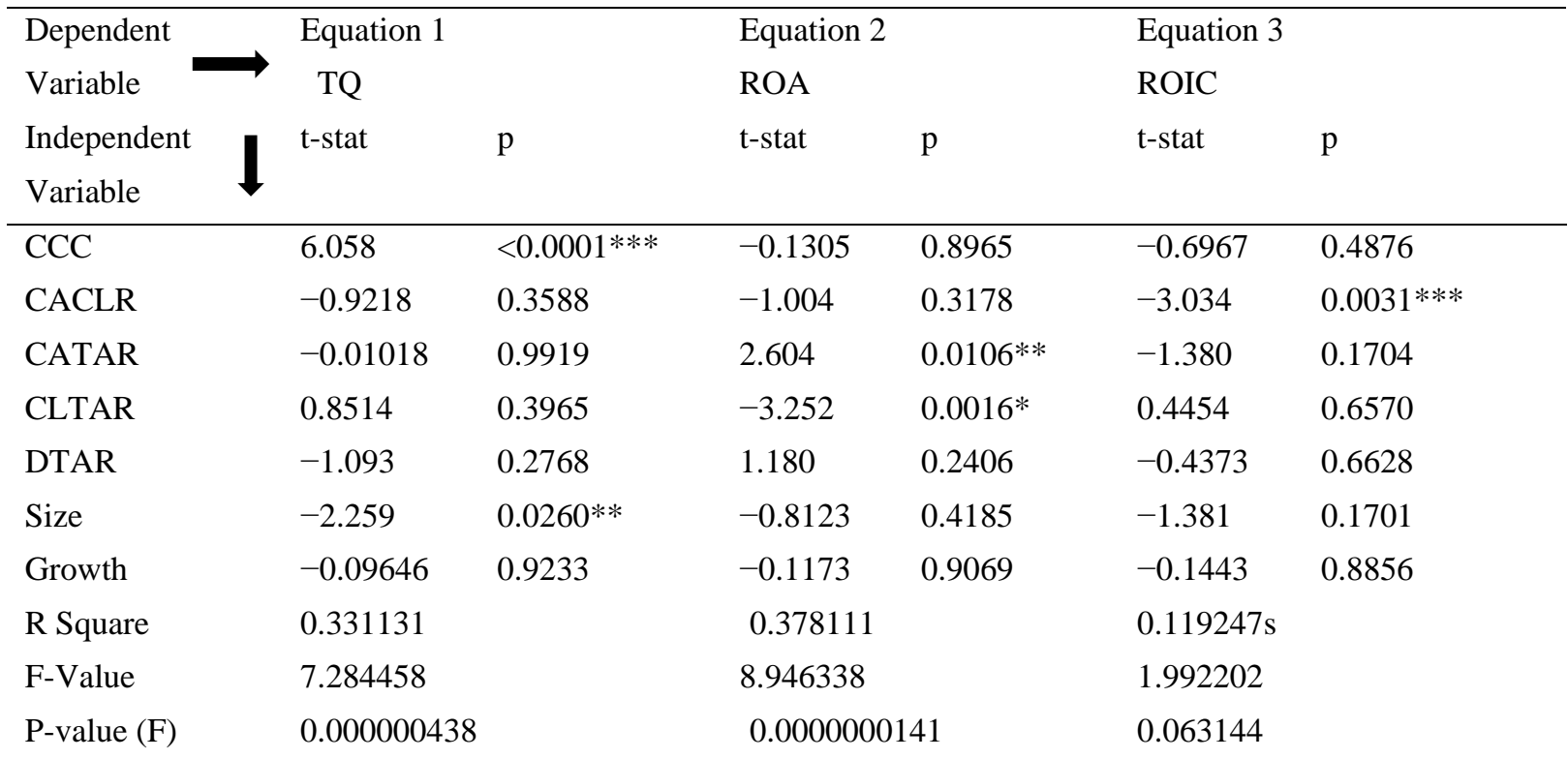

*** Significant level at 1\% $\quad * *$ Significant level at 5\% $\quad *$ Significant level at 10\%

Results indicate that CCC discloses mixed relation where there is a positive significant association with TQ at $1 \%$ significant level and negative insignificant association with ROA and ROIC. This implies that the increase in days sales outstanding \& days sales in inventories and decrease in accounts payable outstanding, affect market value positively. Increase in CCC level, on the other hand affects performance of the firm negatively consistent with existing literature (Shine and Soenen (1998), Padachi (2006) and Christopher and Kamalavalli (2009)). As for CACLR, the result stipulate a $1 \%$ confidence to be negatively related with ROIC but negatively insignificant with TQ and ROA. This shows that the lower current ratio will increase the firm performance which supports the all alternative hypothesis, the changes in TQ, ROA and ROIC can be explained by changes in CACLR. Results for ROIC are similar to the findings in Nazir, (2009) and Afza\&Nazir, (2007) while those of TQ and ROA contradict Afza\&Nazir, (2007) and Nazir, (2009). The regression result for CATAR indicates a positive association with ROA and negative insignificant association with TQ and ROIC indicating that any increase in CATAR will increase ROA and decrease in CATAR will increase TQ \& ROIC and also support alternative hypothesis. This result contradicts with the study done by Nazir, (2009), Afza\&Nazir, (2007). As for CLTAR, there is an insignificant positive relation with TQ and ROIC but have a negative significant association with ROA. That means if current liabilities are decreased than the performance of firm measured by ROA will be increased. The result of DTAR discloses positive insignificant relation with ROA and negative insignificant association with TQ and ROIC. That is the debt to asset ratio does not affect firms value and performance insignificantly. The size of the firm is negatively associate with ROA and ROIC; negative significant association with TQ. As for the growth, the result indicates that there is a negative association with the firm value and performance. Equation 1 shows the value of R-square as .3311 which means that the variance of the dependent variable is explained by independent variable by $33.11 \%$. The F-statistics is 7.284458 and the significance level is 0.000000438 . That means the overall results show that there is a significant positive impact of working capital components on market value. Equation 2 shows the value of R-square is 0.3778 which means that the variance of the dependent variable is explained independent variable by $3778 \%$. The F-statistics is 8.946338and the significance level is 0.0000000141 . That indicates the overall results show that there is a significant positive impact of working capital components on return on asset. In Equation 3, the value of $\mathrm{R}$-square is 0.1192 which means that the variance of the dependent variable is explained independent variable by $11.92 \%$. The F-statistics is 1.992202 and the significance level is 0.063144 . That means the overall results shows that there is an insignificant positive impact between working capital components and return on invested capital.

\subsection{Regression Model for Overall Manufacturing Sector}

To test the effects of working capital management on firm value and profitability, a regression model is given using 56 firm-years observation and the result is presented in Table 5. Here it is observed that CCC has a positive insignificant association with TQ, ROA, and ROIC which support hypothesis $1,2 \& 3$. As for current ratio 
(CACLR), there is a negative association with TQ and ROA and having positive insignificant relation with ROIC. That means current ratio does not affect the market value and the return of the asset but has an effect on ROIC.

Table 5. Regression Model for Overall Manufacturing Sector

\begin{tabular}{|c|c|c|c|c|c|c|}
\hline \multirow{4}{*}{$\begin{array}{l}\text { Dependent } \\
\text { Variable } \\
\text { Independent } \\
\text { Variable }\end{array}$} & \multirow{2}{*}{\multicolumn{2}{|c|}{ Equation 1}} & \multicolumn{2}{|c|}{ Equation 2} & \multicolumn{2}{|c|}{ Equation 3} \\
\hline & & & ROA & & ROIC & \\
\hline & t-stat & $\mathrm{p}$ & t-stat & $\mathrm{P}$ & t-stat & $\mathrm{P}$ \\
\hline & & & & & & \\
\hline CCC & 1.377 & 0.1749 & 0.4495 & 0.6551 & 0.4313 & 0.6682 \\
\hline CACLR & -1.068 & 0.2909 & -1.397 & 0.1689 & 0.5741 & 0.5686 \\
\hline CATAR & 3.729 & $0.0005 * * *$ & 7.750 & $<0.0001 * * *$ & 1.351 & 0.1833 \\
\hline CLTAR & -1.694 & $0.0969 *$ & -2.298 & $0.0261 * *$ & -1.045 & 0.3014 \\
\hline DTAR & 1.951 & $0.0570 *$ & 2.919 & $0.0054 * * *$ & 2.012 & 0.0500 \\
\hline Size & -0.3817 & 0.7044 & -0.6068 & 0.5469 & 0.01211 & 0.9904 \\
\hline Growth & -2.607 & $0.0122^{* *}$ & -2.741 & $0.0086^{* * *}$ & 1.237 & 0.2223 \\
\hline R Square & 0.404488 & & 0.67065 & & 0.148412 & \\
\hline F-Value & 4.560535 & & 13.67259 & & 1.170148 & \\
\hline P-value (F) & 0.000598 & & 0.00000 & & 0.337838 & \\
\hline
\end{tabular}

The regression results for CATAR indicates positive significant association with TQ, ROA at $1 \%$ confidence level and insignificant positive relation with ROIC indicating that any increase in TQ, ROA and ROIC can be explained by an increased in CATAR. Our results match with those of Nazir, (2009) and Afza \& Nazir, (2007) who also indicate similar results for TQ and ROA, while results for ROIC is similar with Christopher and Narware (2004). Based on the results, it can be assumed that the listed firms in Bangladesh tend to rely on the tendency of current asset to generate profit and they have to sustain an optimum daily requirements of current assets in addition to meet their short term maturities, or else profitability may be adversely affected. As for the CLTAR, the result stipulates negative insignificant relation with TQ and ROIC while negative significant relation with ROA indicating the decrease in current asset to total asset ratio positively affects return on asset supporting the findings of Christopher and Kamalavalli (2009) and Shin and Soenen (1998). As depicted by the results of DTAR, the analysis indicate a positive significant association with TQ, ROA, and ROIC which indicates that any increase in debt to total asset ratio, market value and the performance of the firm will also increase. This result is similar with the study done by Sayuddzaman (2006) which finds positive association with performance. The size of the firm is negatively insignificant associated with TQ and ROA; positive insignificant association with ROIC. As for the growth, the result indicates that there is negative significant association with the firm value, Tobin's $Q$ and return on asset but having positive insignificant association with ROIC. R-square in Equation 1 is 0.404488 which means that the variance of the dependent variable is explained by independent variable by $40.45 \%$. The F-statistics is 4.560535 and the significance level is 0.000598 . That means the overall results shows that there is a significant positive impact of working capital components on market value. Equation 2 shows the value of R-square is 0.670656 which means that the variance of the dependent variable is explained independent variable by $67.07 \%$. The F-statistics is 13.67259 and the significance level is 0.00000000172 . That indicates the overall results show that there is a significant positive impact of working capital components on return on asset. In Equation 3, the value of R-square is 0.148412 which means that the variance of the dependent variable is explained independent variable by $14.84 \%$. The F-statistics is 1.170148 and the significance level is 0.337838 . That means the overall results shows that there is an insignificant positive impact between working capital components and return on invested capital.

\subsection{White Test for Heteroscedasticity}

A collection of random variables is heterosecedastic, if there are sub-population that has variability from others. In economic, an extremely common test for heterosecedasticity is the white test, which begins by allowing the heterosecedasticity process to be a function of one or more independent variables. 
Table 6. Test for Heteroscedasticity

\begin{tabular}{llllll}
\hline & & Food Sector & & \multicolumn{2}{c}{ Overall Market Sector } \\
& & R Square & P value & R Square & P value \\
\hline Equation 1 & TQ & 26.929387 & 0.800352 & 47.264329 & 0.080668 \\
Equation 2 & ROA & 109.647260 & 0.000000 & 51.357286 & 0.036677 \\
Equation 3 & ROIC & 52.225429 & 0.023644 & 49.000530 & 0.058370
\end{tabular}

By doing heterosecedasticity test, we find that the P-value is less than 0.05 in the overall market sector which ensure that there is no heteroscedasticity problem in the overall market sector. In food sector, there is no heterosecedasticity in equation $2 \& 3$ as p values are less than 0.05 and have the existence of heteroscedasticity in Equation 1 as P-value is more than 0.05 .

\subsection{Test for Normality}

In statistics, normality tests are used to determine if a data set is well-modeled and how likely it is for a random variable underlying the data set to be normality distributed. The study measures a goodness of fit of a normal model to the data. The skewness measure whether the distribution of the data is symmetrical $r$ asymmetrical. Positive skewness of variables indicates that the distribution of the data series has a long right tail. On the other hand, kurtosis measures the peak and flatness of the distribution of the series. The probability value estimated in Table has failed to reject the null hypothesis that the data series is normally distributed. Table 7 shows graphic prersentation of variables and that all the chosen variables are normally distributed. In Table 8 we show that the P-value is less than 0.05 in the overall market sector for all the equations also confirming that data is normally distributed in the regression model. In the food sector, the result found that the P-value is less than 0.05 for all the equations. So the result indicates that data is normally distributed in the regression model.

Table 7. Graphs of Normality Test

\section{Food Sector}

Equation 1

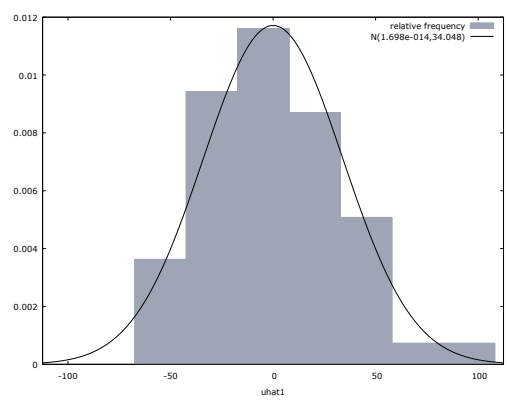

Overall Manufacturing Sector

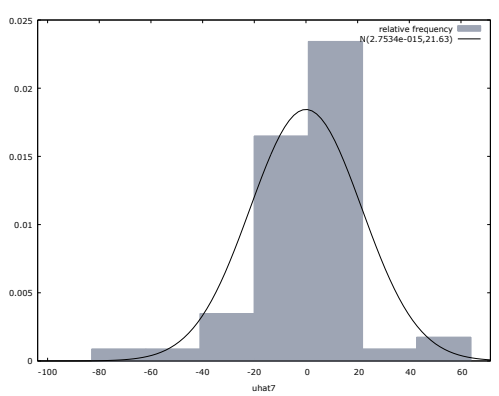

Equation 2

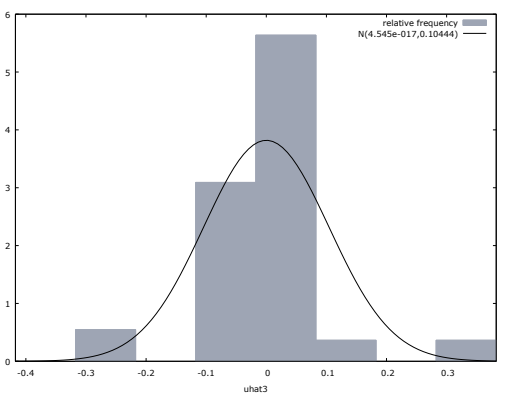

Equation 3

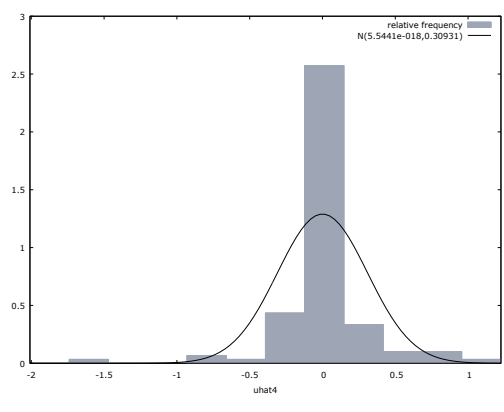


Table 8. Result of Normality Test

\begin{tabular}{llllll}
\hline \multirow{2}{*}{ Model } & & Food Sector & & \multicolumn{2}{c}{ Overall Market Sector } \\
& & Chi-square & P-value & Chi-square & P-value \\
\hline Equation 1 & TQ & 232.026 & 0.00000 & 15.860 & 0.00036 \\
Equation 2 & ROA & 983.619 & 0.000000 & 11.260 & 0.00359 \\
Equation 3 & ROIC & 120.152 & 0.00000 & 28.772 & 0.00000 \\
\hline
\end{tabular}

3.5 Correlation Matrix for Food Sector and Overall Manufacturing Sectors

The correlations between the variables for food sector are reported in the table 9. From the table, the correlation result for Tobin's Q indicate that there is positive relation with CCC $(0.5310)$ while negative correlation with CACLT (-0.0784), CATA (-0.0272), CLTAR (-0.0849), DTAR (-0.1049), SIZE (-0.2432) \& Growth (-0.0387). As for ROA, result described positive correlation with CCC (0.0498), CACLR (0.0088) \& Growth (0.0127), while negative correlation with CATAR (-0.1054), CLTAR (-0.5527), DTAR (-0.1049) \& Size (-0.0183). The correlation between ROIC with all the independent have negative relation. Overall the correlation results indicate both alternative hypothesis $1,2 \& 3$ can be accepted implying a significant correlation exist between working capital management components with firm value and profitability.

Table 9. Pearson Correlation Matrix for the Food Sector

\begin{tabular}{llllll}
\hline TQ & ROA & ROIC & CCC & CACLR & \\
\hline 1.0000 & 0.0681 & 0.0850 & 0.5310 & -0.0784 & TQ \\
& 1.0000 & 0.0572 & 0.0498 & 0.0088 & ROA \\
& & 1.0000 & -0.0430 & -0.2786 & ROIC \\
& & & 1.0000 & -0.0187 & CCC \\
& & & 1.0000 & CACLR \\
CATAR & CLTAR & DTAR & SIZE & GROWTH & \\
-0.0272 & -0.0849 & -0.1049 & -0.2432 & -0.0387 & TQ \\
-0.1054 & -0.5527 & -0.5053 & -0.0183 & 0.0127 & ROA \\
-0.1349 & -0.0278 & -0.0494 & -0.0907 & -0.0023 & ROIC \\
0.0140 & -0.0646 & -0.0639 & -0.1442 & -0.0469 & CCC \\
-0.0363 & -0.1221 & -0.0976 & -0.0227 & -0.0155 & CACLR \\
1.0000 & 0.5476 & 0.5782 & -0.1471 & -0.0562 & CATAR \\
& 1.0000 & 0.9726 & -0.1175 & -0.0305 & CLTAR \\
& & 1.0000 & -0.1221 & 0.0006 & DTAR \\
& & & 1.0000 & -0.0035 & SIZE \\
& & & & 1.0000 & GROWTH
\end{tabular}

The correlations between the variables for overall manufacturing company are reported in the table 10. From the table, the correlation result for Tobin's Q indicate that there is positive relation with CCC (0.5310), CACLT (0.0860), CLTAR (0.0296), DTAR(0.2387) while negative correlation with, SIZE(-0.3776) \& Growth(-0.1746). As for ROA, result described positive correlation with CACLR (0.1358), CATAR (0.7041), CLTAR (0.0882) \& DTAR (0.2387), whilst negative correlation with CCC (-0.0792), Size (-0.3363) \& Growth $(-0.2529)$. The correlation between ROIC with CCC (0.0464), CACLR (0.0449), CATAR (0.2315), CLTAR (0.1488), DTAR (0.3009), Size $(0.0972)$ has positive relation and Growth $(-0.0461)$ has negative association. Overall the correlation results indicates both alternative hypothesis $1,2 \& 3$ can be accepted implying a significant correlation exist between working capital management components with firm value and profitability. 
Table 10. Pearson Correlation Matrix for Overall Manufacturing Sector

\begin{tabular}{llllll}
\hline TQ & ROA & ROIC & CCC & CACLR & \\
\hline 1.0000 & 0.7880 & 0.1394 & 0.0529 & 0.0860 & TQ \\
& 1.0000 & 0.2348 & -0.0792 & 0.1358 & ROA \\
& & 1.0000 & 0.0464 & 0.0449 & ROIC \\
& & & 1.0000 & -0.0724 & CCC \\
& & & 1.0000 & CACLR \\
CATAR & CLTAR & DTAR & SIZE & GROWTH & \\
0.4371 & 0.0296 & 0.2387 & -0.3776 & -0.1746 & TQ \\
0.7041 & 0.0882 & 0.3009 & -0.3363 & -0.2529 & ROA \\
0.2315 & 0.1488 & 0.2640 & 0.0972 & -0.0461 & ROIC \\
-0.0698 & 0.2522 & 0.1020 & 0.1137 & 0.1390 & CCC \\
0.2595 & -0.2920 & -0.2467 & -0.3023 & -0.2090 & CACLR \\
1.0000 & 0.1906 & 0.1555 & -0.0505 & -0.2434 & CATAR \\
& 1.0000 & 0.7369 & 0.2347 & -0.0263 & CLTAR \\
& & 1.0000 & -0.0103 & -0.0617 & DTAR \\
& & & 1.0000 & 0.1676 & SIZE \\
& & & & 1.0000 & GROWTH \\
\hline
\end{tabular}

\section{Conclusion}

In this research, we explore and provide a comparative analysis of the association between working capital management with firm's market value and performance of food sector and overall market sector in the emrging market of Bangladesh. We utilize three model specification in order to test the hypotheses, using market value measure of Tobin's Q and profitability measured by return on asset (ROA) and return on invested capital (ROIC) with seven independent variables. Our findings conclude that there are both positive and negative significant relations between working capital with the firm's performance. The regression support alternative hypothesis $\left(\mathrm{H}_{11}\right.$, $\mathrm{H}_{12}$, and $\mathrm{H}_{13}$ ) as depicted by table $4 \& 5$. We apply stationary test, normality test, correlation, and multiple regression analysis. Our results for both food sector and overall manufacturing companies show that there is significant association with working capital variables of Tobin's Q and ROA with firm's value \& performance but ROIC has insignificant association with firm's performance. Thus it highlights the importance of managing working capital requirements to ensure an improvement in firm's market value and profitability. One possible implication of our research for investors is that individual investor needs to consider the level of efficiency in working capital management before investing in stocks as it may have larger impact in future performance of stocks. It is also safe to suggest that the listed firms in Bangladesh tend to rely on the tendency of current asset to generate profit and they have to sustain optimum daily requirements of current assets in addition to meet their short term maturities, or else profitability will be decreased severely. Our findings also warrant the importance of future research on working capital management using more variables and larger cross sectional and time series data to further enrich the insights into this research.

\section{References}

Altman, E. (1968). Financial Ratios, Discriminant Analysis and the Prediction of Corporate Bankruptcy, Journal of Finance, 189-209. https://doi.org/10.2307/2325319

Abor, J. (2005). Working Capital Management and Corporate Profitability: Evidence from Ghana. LBS Management Review, 9(7), 1093-1099. https://doi.org/10.4314//bsmr.v9i1.24480

Addae, A. A., \& Nyarko-Baasi, M. (2013). Working Capital Management and Profitability: An empirical Investigation in an Emerging Market. Research Journal of Finance and Accounting, 4(15), 2222-2847.

Aguenaou, S., Farooq, O., Abrache, J., \& Brahimi, M. (2016). The Relationship between Working Capital Management and Profitability: Empirical Evidence from Morocco. Global Review of Accounting and Finance, 6(1), 118-139. https://doi.org/10.21102/graf.2015.03.61.08 
Al-Mwalla, Muna. (2012). The impact of Working Capital Management Policies on firm's Profitability and Value: the case of Jordan. International Research Journal of Finance and Economics, 85, 147-153.

Anwar, S. M. R. (2017). Working Capital Management and Profitability: A Study on Cement Industry Working Capital Management and Profitability: A Study on Cement Industry in Bangladesh. (January 2015).

Anagnostopoulou, S. (2013). Working Capital Management and Firm Listing Status. Multinational Finance Journal, Forthcoming, 16(3), 261-301. https://doi.org/10.17578/16-3/4-4

Baghiyan, F. (2013). The Impact of Working Capital Management on Management Performance. Journal of Behavioural Economics, Finance, Entrepreneurship, Accounting and Transport, 1(1), 13-14. https://doi.org/10.12691/JBE-1-1-2

Chowdhury, A., \& Amin, M. (2007). Working Capital Management Practiced in Pharmaceutical Companies Listed in Dhaka Stock. BRAC University Journal, IV(2), 75-86.

Das, A. K., Hoque, M. M., \& Abu Taher, M. (2014). Working Capital Management Practices in Selected Listed Companies of Bangladesh. (December). Retrieved from https://www.researchgate.net/publication/286883256

DEN, M., \& ORUC, E. (2014). Relationship between Efficiency Level of Working Capital Management and Return on Total Assets in ISE (Istanbul Stock Exchange). International Journal of Business and Management, 4(10), 109-114. https://doi.org/10.5539/ijbm.v4n10p109

Deloof, M. (2003). Does working capital management affect profitability of Belgian firms? Journal of business finance \& Accounting, 30(3-4), 573-588. https://doi.org/10.1111/1468-5957.00008

Dixon, R., Guariglia, A., \& Vijayakumaran, R. (2015). Managerial ownership, corporate governance and firms' exporting decisions: evidence from Chinese listed companies. The European Journal of Finance, 1-39. https://doi.org/10.1080/1351847X.2015.1025990

Edi, N., \& Binti, A. (2010). Working Capital Management: The Effect of Market Valuation and Profitability in Malaysia. International Journal of Business and Management, 5(11), 140-147. https://doi.org/10.5539/ijbm.v5n11p140

Filbeck, Greg., \& Krueger, Thomas. M. (2005), "An Analysis of Working Capital Management Results across Industries", American Journal of Business, 20(2), 11- 20. https://doi.org/10.1108/19355181200500007

Ganesan, V. (2007). 3 Measures of Working Capital Management Efficiency, 3(2), 1-10.

García-Teruel, P. J., \& Martínez-Solano, P. (2007). Effects of working capital management on SME profitability. International Journal of Managerial Finance, 3(2), 164-177. https://doi.org/10.1108/17439130710738718

Hill, M., Kelly, G., \& Highfield, M. (2010), Net Operating Working Capital Behavior: A First Look, Financial Management, 39, 783-805. https://doi.org/10.1111/j.1755-053X.2010.01092.x

Kieschnick, R., Laplante, M., \& Moussawi, R. (2013). Working capital management and shareholders' wealth. Review of Finance, 17(5), 1827-1852. https://doi.org/10.1093/rof/rfs043

Kalcheva, I., \& Lins, K. (2007), International Evidence on Cash Holdings and Expected Managerial Agency Problems, Review of Financial Studies, 20, 1087-1112. https://doi.org/10.1093/rfs/hhm023

Lee, K. W., \& Lee, C. F. (2009). Cash holdings, corporate governance structure and firm valuation. Review of Pacific Basin Financial Markets and Policies, 12(3), 475-508. https://doi.org/10.1142/S021909150900171X

Majidmakki, M. A., Saleem, S., \& Aziz, T. (2012). the Relationship of Cash Conversion Cycle and Firm' S Profitability: an Empirical Investigation of Pakistani, 1(1), 80-96.

Meckling, W. H., (1976). Theory of the firm: managerial behaviour, agency costs and ownership structure. Journal of Financial Economics, 3, 305-360. https://doi.org/10.1016/0304-405X(76)90026-X

Petersen, M., \& Rajan, R. (1997), Trade Credit: Theories and Evidence, Review of Financial Studies, 10, 661-691. https://doi.org/10.1093/rfs/10.3.661

Pinkowitz, L., \& Williamson, R. (2007). What is the market value of a dollar of corporate cash? Journal of Applied Corporate Finance, 19(3), 74-81. https://doi.org/10.1111/j.1745-6622.2007.00148.x

Quayyum, S. T. (2012). Relationship between Working Capital Management and Profitability in Context of Manufacturing Industries in Bangladesh. International Journal of Business and Management, 7(1), 58-69. https://doi.org/10.5539/ijbm.v7n1p58 
Raheman, A., \& Nasr, M. (2007). Microsoft Word - Raheman.doc - Paper 19.pdf, 3(1), 279-300. Retrieved from http://www.bizresearchpapers.com/Paper 19.pdf

Rehman, M. U., \& Anjum, N. (2013). Determination of the Impact of Working Capital Management on Profitability: An Empirical Study from the Cement Sector in Pakistan. Asian Economic and Financial Review, 3(3), 3-19.

Richards, V., \& Laughlin, E. (1980), A Cash Conversion Cycle Approach to Liquidity Analysis, Financial Management, 9, 32-38. https://doi.org/10.2307/3665310

Ruback, R., \& Sesia, A., (2000), Dell's Working Capital, Harvard Business School Case, 201-029.

Sartoris, W., \& Hill, N. (1983), "Cash and Working Capital Management”, Journal of Finance, 38, 349-360. https://doi.org/10.2307/2327967

Sayaduzzaman, M. (2007). Working Capital Management: A Study on British American Tobacco Bangladesh Company Ltd. Journal of Nepalese Business Studies, 3(1), 78-84. https://doi.org/10.3126/jnbs.v3i1.484

Schiff, M., \& Lieber, Z. (1974), A Model for the Integration of Credit and Inventory Management, Journal of Finance, 29, 133-140. https://doi.org/10.1111/j.1540-6261.1974.tb00029.x

Shin, H., \& Soenen, L. (1998), Efficiency of Working Capital Management and Corporate Profitability, Financial Practice and Education, 8, 37-45.

\section{Copyrights}

Copyright for this article is retained by the author(s), with first publication rights granted to the journal.

This is an open-access article distributed under the terms and conditions of the Creative Commons Attribution license (http://creativecommons.org/licenses/by/4.0/). 